\title{
CASE STUDY ON CHARACTERISTICS OF EFFECT OF DAMAGE REDUCTION MEASURES AGAINST MULTIPLE DISASTERS OF EARTHQUAKES AND FLOODS
}

\author{
Osamu ITAGAKI ${ }^{1}$, Tatsuro MATSUURA ${ }^{2}$ and Atsushi HATTORI ${ }^{3}$ \\ ${ }^{1}$ Ministry of Land, Infrastructure, Transport and Tourism (MLIT), ex-Senior Researcher, River \\ Division, River Department, National Institute for Land and Infrastructure Management (NILIM), \\ Tsukuba, Japan, itagaki-o@outlook.jp \\ ${ }^{2}$ Senior Researcher, Waste Water System Division, Water Quality Control Department, NILIM, MLIT, \\ Tsukuba, Japan \\ ${ }^{3}$ Dr. Eng., ex-Head, River Division, River Department, NILIM, MLIT, Tsukuba, Japan
}

\begin{abstract}
We applied an analysis method for estimating the potential direct economic damage and death toll caused by multiple disasters of earthquakes and floods. To extract the effects of various measures in the analysis, we used a river about $60 \mathrm{~km}$ long as our case study. We assumed a set of multiple disasters in which one of two floods occurs after one of three earthquakes and estimated the damage in the river. We estimated the damage in 120 cases by changing the scales of each earthquake and each flood, the interval between the earthquake and flood, and the needed disaster damage reduction measures.
\end{abstract}

Key Words: Multiple disaster, earthquake, flood, flood damage reduction, direct economic damage, death toll

\section{INTRODUCTION}

Since the Great East Japan Earthquake in 2011, it has been recognized that developing disaster damage reduction measures in advance against a catastrophic or even a low-frequency disaster is an important responsibility. In river disaster areas, damage reduction measures against a tsunami ${ }^{1)}$ or a catastrophic scale of floods due to global climate change ${ }^{2)}$ have been discussed. As another example, we can suppose multiple disasters, where a flood and an earthquake occur at the same time or one just after the other. In past occurrences, such as the Fukui Earthquake in 1948 and the Niigata-ken Chuetsu Earthquake in 2004, heavy rainfall occurred in the month before or after the earthquake and the area suffered great damage ${ }^{3)}$. It has been pointed out that a new concept is necessary to decide the appropriate priorities of recovery and reconstruction work after a disaster, with consideration of the probabilities of a following disaster due to an increase of extreme climate events caused by global climate change $e^{4)}$.

In this paper, we applied the analysis method proposed by Matsuura et al. ${ }^{5)}$ for multiple disaster cases. We systematically estimated potential disaster damage and the effects of damage reduction 
measures, and then extracted the characteristics of disaster damage reduction measures from the point of view of multiple disasters. Our case study was of a river, and the disasters were a flood and an earthquake.

\section{FRAMEWORK FOR DISCUSSING DISASTER DAMAGE REDUCTION MEASURES AGAINST MULTIPLE DISASTERS OF EARTHQUAKES AND FLOODS}

In the case of multiple disasters where a river flood follows an earthquake, the damage caused by the earthquake to river structures and buildings in the floodplain (the area protected by riverine levees) differs as the scale of the earthquake changes, and the number of days necessary for the recovery also differs. In general, the larger the scale of the earthquake is, the larger and more extensive the damage and the longer the period necessary for recovery are. It is possible that flood damage would be larger when a flood occurs in an area before reconstruction has progressed, such as a flood just after an earthquake. In this situation, it is not enough to focus on the scales of the earthquake and the flood only, but it is important to introduce the time series of the restoration process when discussing the disaster damage reduction measures against the multiple disasters. In this study, the time series of the restoration processes of housing, roads, electricity, river structures, etc., were organized, and estimation of the number of days until each restoration state begins and the extent of flood damage in each restoration state was conducted. Finally, the effects of disaster reduction measures were estimated and analyzed.

Disaster damage, such as the death toll and the number of days necessary for restoration in the area, was estimated by systematically changing the scales of the earthquake and the flood, and the interval between them. The estimation was conducted for the case study of a river $60 \mathrm{~km}$ in length. The case study river was set under the assumption that the Minister of Land, Infrastructure, Transport and Tourism (MLIT) was directly managing the sections of such A-class rivers in Japan. The influence of earthquake damage on the restoration process was based on past examples. In addition, we set the damage by ground shake as the main target in this study, and so the damage caused by a tsunami or land subsidence except for the levee subsidence was not considered. Also, the simultaneous occurrence of a storm surge with the flood was not considered.

\section{CONFIGURATIONS OF CASE STUDY RIVER, EARTHQUAKE AND FLOOD FOR ESTIMATION OF DAMAGE BY MULTIPLE DISASTERS}

The configuration of the case study river and the floodplain is shown in Table 1, and the conditions of the river and the floodplain according to the progress of restoration after the earthquake are shown in Table 2. The land use and the ground height of the floodplain are shown in Fig. 1. The left bank of the

Table 1 Configuration of target river and floodplain

\begin{tabular}{|l|l|l|}
\hline \multirow{4}{*}{ River } & Length of main river & About $200 \mathrm{~km}$ \\
\cline { 2 - 3 } & Watershed area & About $5,000 \mathrm{~km}^{2}$ \\
\hline \multirow{5}{*}{ Floodplain } & $\begin{array}{l}\text { Length of river section } \\
\text { managed by MLIT directly }\end{array}$ & About $60 \mathrm{~km}$ \\
\cline { 2 - 3 } & Area & About $600 \mathrm{~km}^{2}$ \\
\cline { 2 - 3 } & Riverbed gradient & About $1 / 500-1 / 5000$ \\
\cline { 2 - 3 } & Population & About $2,200,000$ \\
\cline { 2 - 3 } & Value of assets & About 6.9 billion yen \\
\cline { 2 - 3 } & Land use & $\begin{array}{l}\text { Building site: } 29 \%, \text { Farmland: } 37 \%, \\
\text { Open water: } 14 \%, \text { Others: } 20 \%\end{array}$ \\
\hline
\end{tabular}


lower reach of the river is in a low-lying area, and the floodplain behind the bank is susceptible to flooding. The right bank of the lower reach is directly connected to the mountains (i.e., no floodplain behind the bank).

As shown in Fig. 2, we set three scales of an earthquake with a distribution of Japan Meteorological Agency seismic intensity in a $250 \mathrm{~m}$ mesh, based on the prediction results for a massive Nankai Trough earthquake ${ }^{\text {) }}$ (referred to as L2 in this study) and a Tohkai, Tonankai, or Nankai earthquake (each is the typical earthquake name which historically caused the periodical huge damage in Japan) ${ }^{7)}$ (L1) from the Central Disaster Prevention Council, Cabinet Office, Government of Japan. These are L2, with a maximum JMA seismic intensity in the area of 6.5; L1', with a maximum JMA seismic intensity of 6.2 (the average of the L2 and L1 earthquakes); and L1, with a maximum JMA intensity of 5.8. Note that these definitions are adopted for descriptive purposes and differ from

Table 2 Assumed conditions of target river and floodplain according to progress of restoration after earthquake

\begin{tabular}{|l|l|c|}
\hline Progress after earthquake & \multicolumn{1}{|c|}{ Condition of target river and floodplain } & $\begin{array}{c}\text { Label in } \\
\text { Fig. 7 }\end{array}$ \\
\hline \hline Just after the earthquake & $\begin{array}{l}\text { Impossible to evacuate to outer area since roads are not } \\
\text { cleared of obstacles yet. Emergency levee } \\
\text { reconstruction has not been started yet. }\end{array}$ & I \\
\hline $\begin{array}{l}\text { Just after main roads } \\
\text { cleared of obstacles }\end{array}$ & $\begin{array}{l}\text { Main road has been cleared of obstacles. Emergency } \\
\text { levee reconstruction has not been started yet. }\end{array}$ & II \\
\hline $\begin{array}{l}20 \% \text { of emergency levee } \\
\text { reconstruction completed }\end{array}$ & $\begin{array}{l}\text { Left bank of the priority section (from } 10.0 \text { to } 23.2 \mathrm{~km} \\
\text { posts) has been remounded up to } 1.6 \mathrm{~m} \text { lower than } \\
\text { HWL. }\end{array}$ & III \\
\hline $\begin{array}{l}50 \% \text { of emergency levee } \\
\text { reconstruction completed }\end{array}$ & $\begin{array}{l}\text { Emergency levee reconstruction of left bank of priority } \\
\text { section has been completed. }\end{array}$ & IV \\
\hline $\begin{array}{l}\text { Emergency levee } \\
\text { reconstruction completed }\end{array}$ & Emergency levee reconstruction has been completed. & V \\
\hline
\end{tabular}
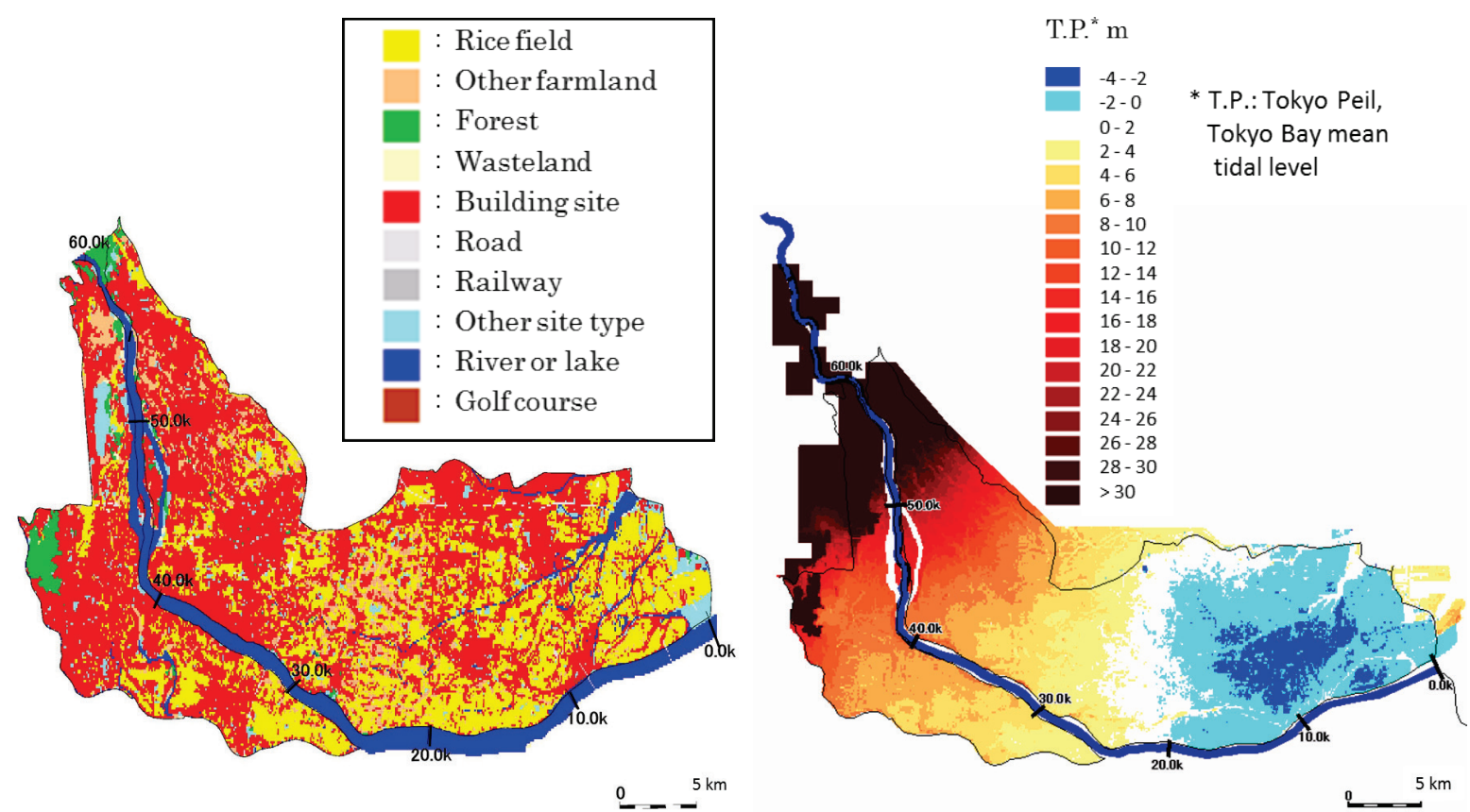

Fig. 1 Configuration of target area (Left: Land use, Right: Ground height) 

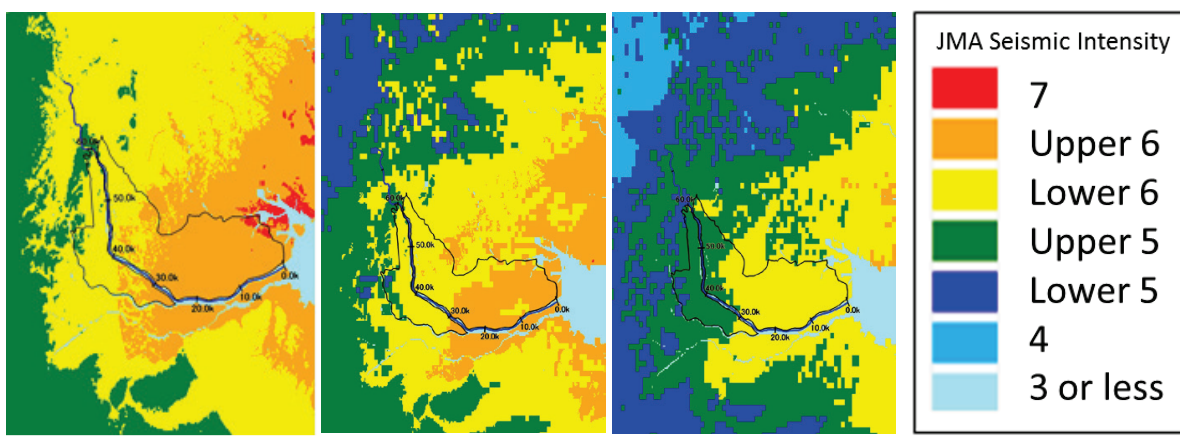

Fig. 2 Assumed JMA seismic intensity (Left: L2, Middle: L1', Right: L1)

the general definitions usually used in Japan. For the flood, we set two scales: one named $\mathrm{F}_{\mathrm{b}}$ with a peak flood discharge of about $15,000 \mathrm{~m}^{3} / \mathrm{s}$ at the upstream end of the river (this flood is similar in scale to the design flood), and a second scale named $F_{c}$ with a current discharge capacity of about $8,000 \mathrm{~m}^{3} / \mathrm{s}$.

The estimation was conducted for each restoration state, in which the evacuation and emergency reconstruction states in the area differed, as shown in Table 2. The emergency reconstruction (re-mounding) of the subsided levee after the earthquake was assumed to be conducted up to the high-water level (HWL). The section from the 10 to $23.2 \mathrm{~km}$ posts of the left bank, where the potential flood damage was estimated to be comparatively large, was prioritized in the emergency reconstruction.

\section{ASSUMED DAMAGE BY EARTHQUAKE}

The flowchart for the assumed damage caused by the earthquake, the restoration process, and the damage caused by the flood is shown in Fig. 3. The number of households that could not receive the flood alert because of a power outage, road damage, building damage, human suffering, and the amount of the levee subsidence were estimated as follows.

\subsection{Number of households where it was impossible to receive flood alert}

We assumed the following rates of power outage just after the earthquake: $96 \%$ for a JMA seismic intensity of lower 6 or more, $43 \%$ for an intensity of upper $5,22 \%$ for an intensity of lower $5,13 \%$ for an intensity of 4 , and $0 \%$ for an intensity of 3 or less based on the examples after the Great East Japan Earthquake ${ }^{8}$. The recovery rate according to the number of days after the earthquake was assumed (e.g., $90 \%$ recovery after one week from the earthquake) by referring to the damage estimation technique for the massive Nankai Trough Earthquake (hereinafter, "Nankai Trough assuming technique") developed by the Central Disaster Prevention Council ${ }^{9)}$, and the evacuation rate in each mesh was decreased according to the estimated number of households in the power outage (i.e., number of households with residents who could not evacuate before the flood). In this study, the power outage rate and the restoration process were roughly assumed, but the rate and the process can be estimated more accurately by using a more detailed method, such as that proposed by Shoji et al. ${ }^{10) 11)}$.

\subsection{Estimation of required number of days for emergency road clearance and of building damage}

We assumed that the number of days required for emergency road clearance after the L2 earthquake was three according to the "2012 Teeth Comb Strategy in Chubu Region"12), and three for L1', and two for L1 corresponded to the ratio of the number of the damaged sites along the emergency transportation roads to that of $\mathrm{L} 2$. The number of damaged sites was estimated by multiplying the 
"length of emergency transportation roads in each JMA seismic intensity (km)" by the "number of damaged sites according to the JMA seismic intensity (sites $/ \mathrm{km}$ )" based on the Nankai Trough assuming technique. A more exact estimate than that in the present study could be obtained by applying newer techniques, such as that of Shoji and Nakamura ${ }^{13)}$; however, the simpler technique applied here is sufficient for the purpose of the present study.

The number of houses completely or partially destroyed by the earthquake was estimated through the Nankai Trough assuming technique, and the fraction of damaged evacuation centers (unusable) was estimated based on the fraction of completely or partially destroyed houses in the area.

\subsection{Estimation of human suffering}

The number of deaths, the number of people needing to be rescued (unable to escape from a destroyed house without assistance), and the number of evacuees (Table 3) were estimated from the number of houses completely or partially destroyed by the Nankai Trough assuming technique based on JMA seismic intensity, number of houses by type of structure, and construction year in each mesh. It should be noted that the number of houses partially destroyed was estimated from the ratio of the number of houses partially destroyed to that completely destroyed by the Nankai Trough assuming technique

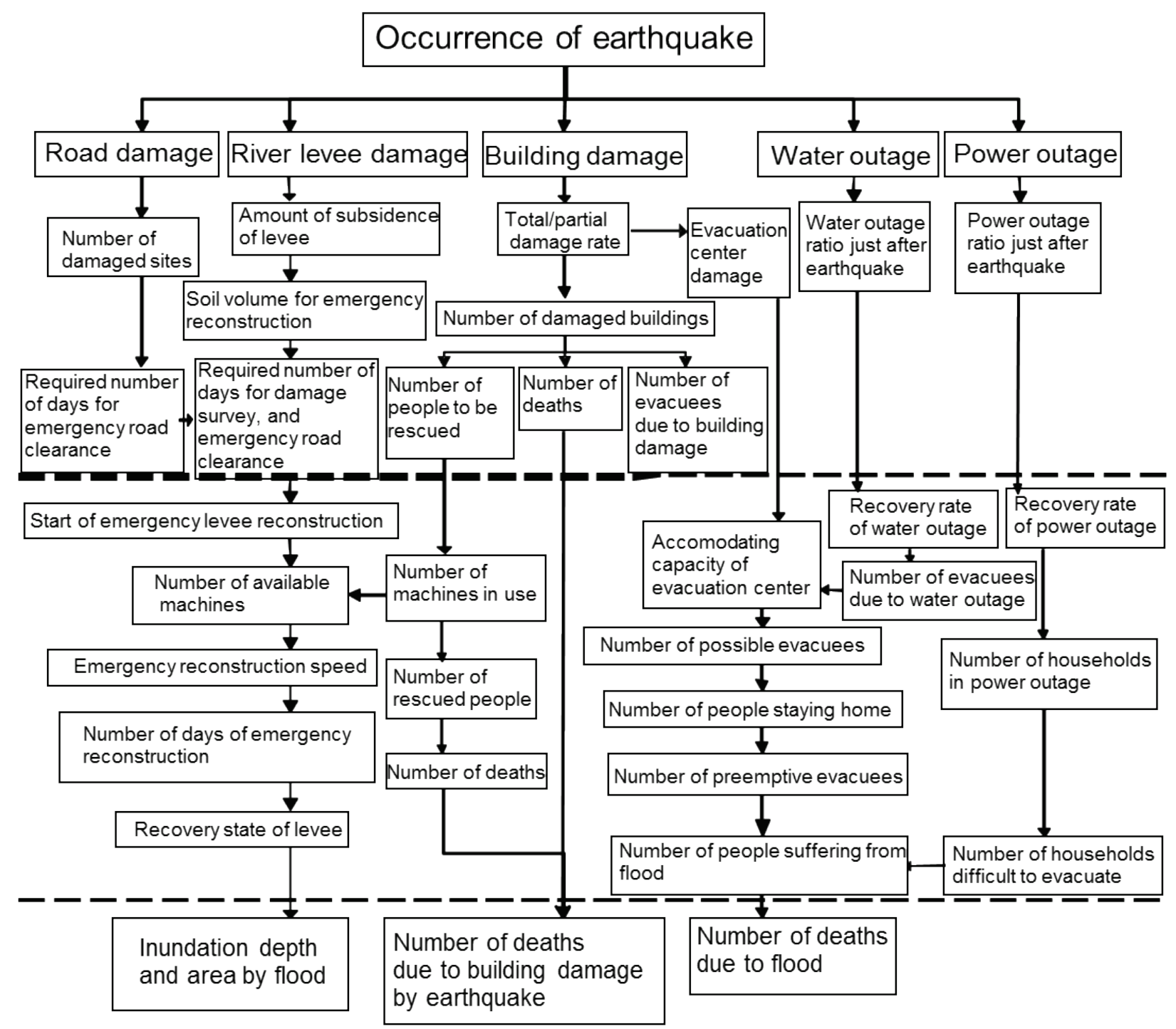

Fig. 3 Flowchart of assumed damage from earthquake to flood 
based on construction year. Estimation on a midnight earthquake case was adopted, because the number of deaths in this case was the most due to the high (100\%) percentage of people at home when the earthquake hit the area. By referring to the examples during the Great Hanshin-Awaji Earthquake ${ }^{14)}$, the survival rate of people needing to be rescued was assumed to be $75 \%$ within a day after the earthquake (day 1), 25\% in day $2,15 \%$ in day 3 , and $0 \%$ in day 4 and beyond. The number of evacuees was estimated by referring to the Nankai Trough assuming technique based separately on the building damage and water outage ratio. The water outage ratio just after the earthquake was estimated based on Kawakami's method ${ }^{15)}$, which assumes water pipes to be cast iron pipes. The water recovery rate was assumed to be $0 \%$ for the first 4 days after the earthquake, and the recovery work was assumed to be started on day 5 and completed on day 28 (the recovery rate was assumed to be primarily proportional to the number of the days from the start of the recovery work), according to the Business Continuity Plan ${ }^{16)}$ of water operators in urban areas. The number of evacuees due to water outage changed in the time series according to the "index of life difficulties under water outage" $"$ ). It was assumed that the excess number of evacuees over the accommodating capacity of evacuation centers in the area were safely evacuated to outside of the area after the emergency road clearance. The technique for estimating the process of water recovery is further explained in, e.g., Nagata et al. ${ }^{17}$, and similarly, the technique for the number of evacuees after failures of critical (life-support) systems in, e.g., Tokyo Metropolitan Government ${ }^{18)}$.

Table 3 Estimation of earthquake damage

\begin{tabular}{|c|c|c|c|c|c|}
\hline \multicolumn{3}{|c|}{ Scale of earthquake } & L2 & L1' & L1 \\
\hline \multicolumn{3}{|c|}{ Population in the area } & \multicolumn{3}{|c|}{$2,200,000$} \\
\hline \multicolumn{3}{|c|}{ Number of households in the area } & \multicolumn{3}{|c|}{780,000} \\
\hline \multicolumn{3}{|c|}{ Number of houses in the area } & \multicolumn{3}{|c|}{580,000} \\
\hline \multirow{3}{*}{ Number of destroyed houses } & \multicolumn{2}{|c|}{ Completely destroyed } & $\overline{57,000}$ & 21,000 & 420 \\
\hline & \multicolumn{2}{|c|}{ Partially destroyed } & 220,000 & 120,000 & 1,800 \\
\hline & \multicolumn{2}{|l|}{ Total } & 270,000 & 140,000 & 2,200 \\
\hline \multicolumn{3}{|c|}{ Number of households in power outage just after earthquake } & 730,000 & 680,000 & 360,000 \\
\hline \multirow{4}{*}{$\begin{array}{l}\text { Human suffering due to collapse of } \\
\text { houses }\end{array}$} & \multicolumn{2}{|c|}{ Number of deaths } & 3,400 & 1,200 & 25 \\
\hline & \multicolumn{2}{|c|}{ Number of people needing to be rescued } & 26,000 & 9,300 & 190 \\
\hline & \multicolumn{2}{|c|}{ Number of people rescued } & 1,100 & 1,100 & 160 \\
\hline & \multicolumn{2}{|c|}{ Number of people dead when found } & 25,000 & 8,300 & 30 \\
\hline \multicolumn{3}{|c|}{ Number of deaths due to earthquake } & 28,000 & 9,500 & 55 \\
\hline \multicolumn{3}{|c|}{ Number of people in water outage just after earthquake ${ }^{*}$} & $1,700,000$ & $1,700,000$ & $1,200,000$ \\
\hline \multicolumn{3}{|c|}{ Number of evacuees due to destroyed buildings } & 240,000 & 84,000 & 1,500 \\
\hline \multicolumn{3}{|c|}{ Maximum number of evacuees due to water outage } & 450,000 & 460,000 & 320,000 \\
\hline \multicolumn{3}{|c|}{ Total } & 690,000 & 550,000 & 320,000 \\
\hline \multirow{2}{*}{$\begin{array}{c}\text { Accomodating capacity of } \\
\text { evacuation centers }\end{array}$} & \multicolumn{2}{|c|}{ Maximum capacity without earthquake } & \multicolumn{3}{|c|}{330,000} \\
\hline & \multicolumn{2}{|c|}{ Maximum capacity after earthquake } & 180,000 & 250,000 & 330,000 \\
\hline \multirow{4}{*}{ Number of evacuees } & \multirow{2}{*}{$\begin{array}{c}\text { Peak number of evacuees } \\
\text { due to water outage }\end{array}$} & In the area & 180,000 & 250,000 & 320,000 \\
\hline & & Out of the area & 510,000 & 290,000 & 0 \\
\hline & \multirow{2}{*}{$\begin{array}{c}\text { After recovery of water } \\
\text { supply }\end{array}$} & In the area & 180,000 & 84,000 & 1,500 \\
\hline & & Out of the area & 60,000 & 0 & 0 \\
\hline \multirow{2}{*}{$\begin{array}{c}\text { Number of people staying home } \\
\text { after earthquake }\end{array}$} & \multicolumn{2}{|c|}{$\begin{array}{c}\text { Peak number of evacuees due to water } \\
\text { outage }\end{array}$} & $1,500,000$ & $1,600,000$ & $1,900,000$ \\
\hline & \multicolumn{2}{|c|}{ After recovery of water supply } & $1,900,000$ & $2,100,000$ & $2,200,000$ \\
\hline \multicolumn{3}{|c|}{ Direct economic damage due to earthquake (ten billion yen) } & 2,600 & 1,700 & 19 \\
\hline
\end{tabular}

* "Number of people in water outage" does not include "Number of people needing to be rescued". 


\subsection{Estimation of amount of levee subsidence by earthquake}

The amount of subsidence at the top of the levee (except for the right bank of the lower reach, which does not have a floodplain behind the levee) by the earthquake was estimated for each $200 \mathrm{~m}$ kilo-post, as shown in Fig. 4. The amount of subsidence was estimated by applying the simple formula from the riverine levee seismic inspection manual ${ }^{19)}$ but partially corrected by using the levee seismic performance verification ${ }^{20)}$ result, i.e., the estimation by the simple formula was corrected for the case of $\mathrm{Kh}=0.4$ by plate-type ground motion. The maximum amount of subsidence was set to be $75 \%$ of the levee height. A slight difference appears in the amount of the subsidence according to the scale of the earthquake in the upstream sections (from the $40 \mathrm{~km}$ post upward) of the left bank, but no clear difference appears in other sections.

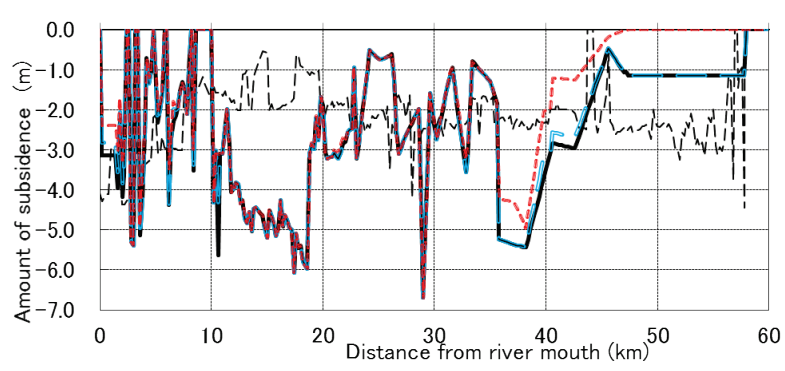

(a) Left bank

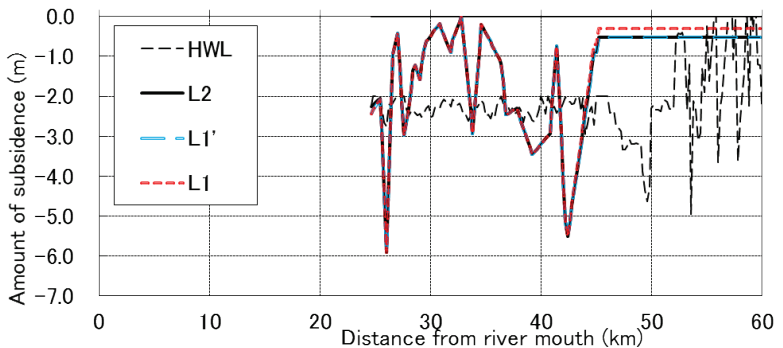

(b) Right bank

Fig. 4 Longitudinal view of estimated levee subsidence

\section{ASSUMPTION OF POST-EARTHQUAKE EMERGENCY RESPONSE BEFORE FLOOD}

\subsection{Assumption of number of machines available for post-earthquake emergency response}

The number of machines available for the post-earthquake emergency response was assumed based on the number of machines owned by the contractors (hereinafter "agreed contractors") that had made an agreement with the river administrator in advance of the post-disaster emergency response. It was assumed that only the machines of the agreed contractors located in the target area were considered available before the emergency road clearance. After the emergency road clearance, all of the agreed contractors in the target municipalities were considered available. It should be noted that a target municipality's area includes the target area. The ratio of the number of machines used in the rescue

Table 4 Assumption of number of machines available for post-disaster emergency response

\begin{tabular}{|c|c|c|c|c|c|c|}
\hline & \multicolumn{2}{|c|}{ Backhoes } & \multicolumn{2}{|c|}{ Bulldozers } & \multicolumn{2}{|c|}{ Dump trucks } \\
\hline & \begin{tabular}{|l|} 
Emergency \\
levee \\
reconstruction
\end{tabular} & \begin{tabular}{|l|} 
Total owned by \\
agreed \\
contractors
\end{tabular} & \begin{tabular}{|l|} 
Emergency \\
levee \\
reconstruction
\end{tabular} & $\begin{array}{l}\text { Total owned by } \\
\text { agreed } \\
\text { contractors }\end{array}$ & \begin{tabular}{|l|} 
Emergency \\
levee \\
reconstruction \\
\end{tabular} & $\begin{array}{l}\text { Total owned by } \\
\text { agreed } \\
\text { contractors }\end{array}$ \\
\hline $\begin{array}{l}\text { Before emergency road } \\
\text { clearance }\end{array}$ & 0 & 228 & 0 & 51 & 0 & 200 \\
\hline $\begin{array}{l}\text { After emergency road } \\
\text { clearance, but before } \\
\text { starting emergency levee } \\
\text { reconstruction }\end{array}$ & 0 & 447 & 0 & 100 & 0 & 480 \\
\hline $\begin{array}{l}\text { Up to day } 10 \text { from } \\
\text { starting of emergency } \\
\text { levee reconstruction }\end{array}$ & 89 & 447 & 20 & 100 & 96 & 480 \\
\hline $\begin{array}{l}\text { Beyond day } 10 \text { from } \\
\text { starting of emergency } \\
\text { levee reconstruction }\end{array}$ & 89 & 447 & 20 & 100 & 336 & 480 \\
\hline
\end{tabular}


work to the number used in the emergency levee reconstruction was assumed to be 4 for backhoes and bulldozers, and 4 for dump trucks up to day 10 from the starting day of emergency reconstruction, and $3 / 7$ beyond. After completion of the rescue work, the ratio was assumed to be $0^{5)}$ (Table 4).

\subsection{Assumption of rescue work from damaged houses}

It was assumed that the rescue work was conducted by the fire department, as shown in Table 5 . The number of rescue teams was limited to the number of backhoes in this study. The possible number of rescued people per day is shown in Table 6. The possible number of rescued people per day was estimated by assigning the number of rescue teams according to the ratio of the number of wooden houses damaged to the number of non-wooden houses damaged.

Table 5 Configuration of assumed rescue work

\begin{tabular}{|c|c|c|c|c|c|c|}
\hline \multirow{2}{*}{$\begin{array}{l}\text { Number of personnel } \\
\text { in fire department }{ }^{* 1}\end{array}$} & \multirow{2}{*}{$\begin{array}{l}\text { Number of personnel } \\
\text { for rescue work }{ }^{* 2}\end{array}$} & \multirow{2}{*}{\multicolumn{2}{|c|}{$\begin{array}{l}\text { Rescue team } \\
\text { composition }\end{array}$}} & \multicolumn{2}{|c|}{$\begin{array}{c}\text { Time required for rescue of } \\
\text { one person }^{21)}\end{array}$} & \multirow{2}{*}{ Working time per day } \\
\hline & & & & $\begin{array}{c}\text { Wooden } \\
\text { house }\end{array}$ & $\begin{array}{c}\text { Non-wooden } \\
\text { house }\end{array}$ & \\
\hline 5,900 & 4,500 & $\begin{array}{c}5 \\
\text { persons }\end{array}$ & 1 backhoe $^{* 3}$ & 117 minutes & 252 minutes & 9 hours \\
\hline
\end{tabular}

*1 Assumed from the annual report of fire department with the similar scale of floodplain.

*2 Assumed to be $75 \%$ of the number of the fire department personnel considering personnel not available for the rescue work, such as the emergency personnel, and communication and command personnel.

*3 From an interview survey of Sendai General Construction Association and Miyagi Demolition Work Business Cooperative on the Great East Japan Earthquake.

Table 6 Assumed rescue rate from collapsed houses

\begin{tabular}{|c|c|c|c|c|c|c|c|}
\hline & \multirow{2}{*}{$\begin{array}{c}\text { Number of } \\
\text { rescue } \\
\text { teams }\end{array}$} & \multicolumn{2}{|c|}{$\begin{array}{c}\text { Rescue rate } \\
\text { (persons/team/day) }\end{array}$} & \multirow{2}{*}{$\begin{array}{c}\text { Possible } \\
\text { number of } \\
\text { people rescued } \\
\text { per day }\end{array}$} & \multicolumn{3}{|c|}{$\begin{array}{c}\text { Necessary number of } \\
\text { days for completing } \\
\text { rescue work }\end{array}$} \\
\hline & & $\begin{array}{c}\text { Wooden } \\
\text { house }\end{array}$ & $\begin{array}{c}\text { Non-wooden } \\
\text { house }\end{array}$ & & L2 & L1' & $\mathrm{L} 1$ \\
\hline Before emergency road clearance & 228 & \multirow{3}{*}{4.6} & \multirow{3}{*}{2.1} & 933 & \multirow{3}{*}{23} & \multirow{3}{*}{10} & \multirow{3}{*}{1} \\
\hline $\begin{array}{l}\text { After emergency road clearance, but before } \\
\text { starting emergency levee reconstruction }\end{array}$ & 447 & & & 1,832 & & & \\
\hline After starting emergency levee reconstruction & 358 & & & 1,466 & & & \\
\hline
\end{tabular}

\subsection{Assumption of emergency levee reconstruction}

It was assumed that emergency levee reconstruction was started after the emergency road clearance

Table 7 Estimated emergency levee reconstruction

\begin{tabular}{|c|c|c|c|c|c|c|}
\hline \multirow{2}{*}{$\mid \begin{array}{l}\text { Scale of } \\
\text { earthquake }\end{array}$} & \multirow{2}{*}{$\begin{array}{c}\text { Necessary soil } \\
\text { volume } \\
\left(\mathrm{m}^{3}\right)\end{array}$} & \multicolumn{4}{|c|}{ Mounding volume per day ( $\mathrm{m}^{3} /$ day) } & \multirow{2}{*}{$\begin{array}{l}\text { Necessary number of } \\
\text { days for completing } \\
\text { emergency levee } \\
\text { reconstruction }^{*}\end{array}$} \\
\hline & & $\begin{array}{c}\text { Up to day } \\
10^{*}\end{array}$ & $\begin{array}{l}\text { From day } 11 \\
\text { to day } 15\end{array}$ & $\begin{array}{c}\text { From day } 16 \\
\text { to day } 23\end{array}$ & $\begin{array}{c}\text { Day } 24 \text { and } \\
\text { beyond }\end{array}$ & \\
\hline L2 & $1,438,085$ & 16,000 & 16,000 & 21,000 & 80,000 & 37 \\
\hline L1' & $1,379,007$ & 16,000 & 80,000 & 80,000 & 80,000 & 27 \\
\hline L1 & $1,132,027$ & 80,000 & 80,000 & 80,000 & - & 20 \\
\hline
\end{tabular}

* Including the 5 days of the levee damage survey. 
and the levee damage survey after the earthquake. The number of days necessary for the levee damage survey was assumed to be five, regardless of the scale of the earthquake, by referring to the examples of the rate of the levee damage survey per day conducted after the Great East Japan Earthquake in 2011 and the Niigata-ken Chuetsu-oki Earthquake in 2007. It was assumed that the emergency levee reconstruction was executed 24 hours a day. The necessary soil volume and the maximum mounding amount per day are shown in Table 7. A clear difference occurs among the necessary number of days for completing the emergency levee reconstruction, because the mounding volume per day was influenced by the limited number of machines available due to the rescue work in the area, even though no such difference occurs among the amounts of levee subsidence by the earthquakes.

\section{ESTIMATION AND ANALYSIS ON DAMAGE CHARACTERISTICS OF MULTIPLE DISASTERS}

The flood simulation was conducted based on the Flood Control Economic Survey Manual (draft) ${ }^{22)}$ as follows:

(a) The river water level was estimated through the sequential one-dimensional calculation.

(b) If the river water level was higher than the water level corresponding to the harmless discharge (hereinafter, "harmless water level"), the levee at that point breached at that moment. The harmless water level was set lower by the amount of subsidence after the earthquake, but the harmless water level was set no lower than the seismic performance verification water level ${ }^{20}$ and the levee breach basement level.

(c) The maximum inundation depth by the $250 \mathrm{~m}$ mesh was estimated through two-dimensional unsteady flow calculation. formula:

The direct economic damage by mesh and by asset type was estimated based on the following

"Direct economic damage" = "Damage ratio according to the maximum inundation depth by asset type" $\times$ "Remaining asset value after the earthquake"

The number of deaths by the flood was estimated for the mesh by assuming the calculation requirements from the influence of the earthquake, as shown in Fig. 5 and Table 8, based on the technique developed by referring to the LIFESim model ${ }^{23)}$, as follows:

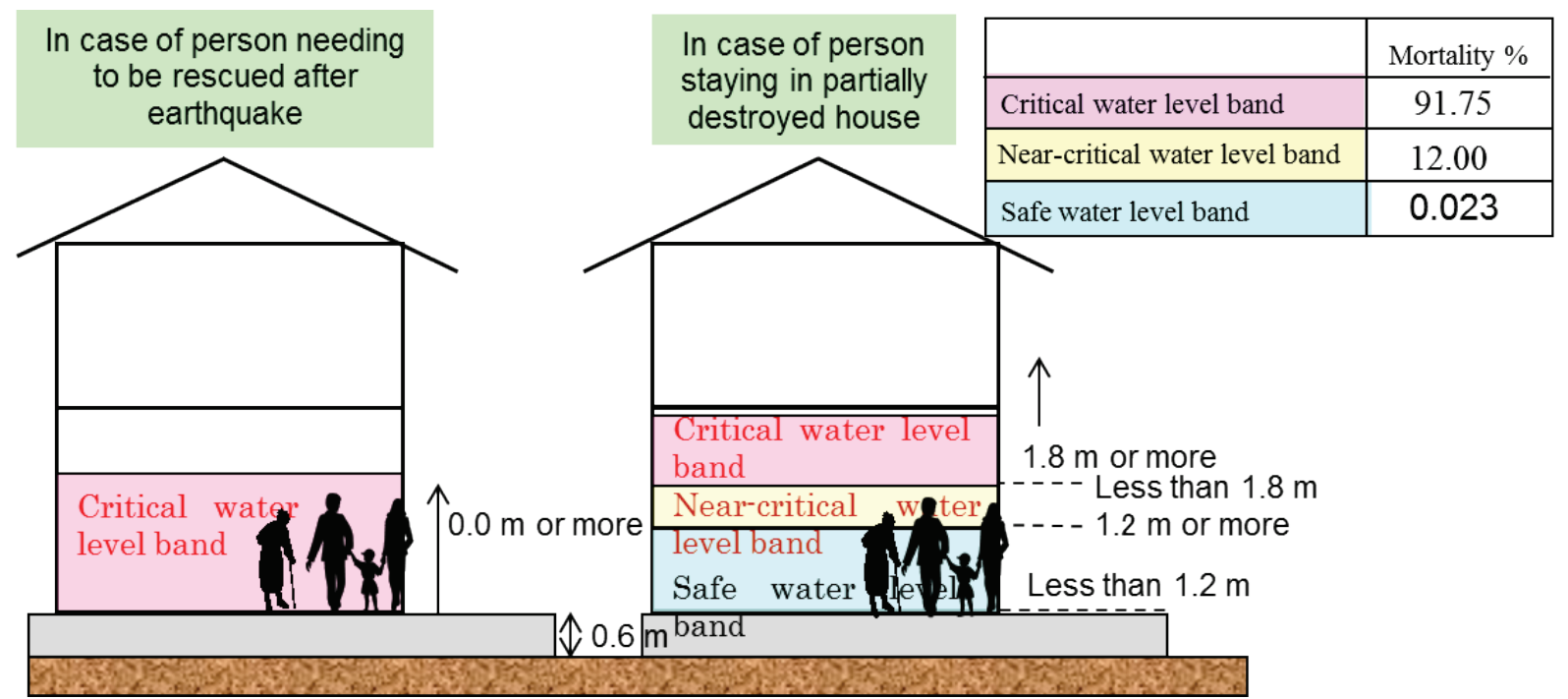

Fig. 5 Assumption of mortality due to flood considering house damage by earthquake 
Table 8 Calculation requirements for number of deaths by flood

\begin{tabular}{|l|l|}
\hline $\begin{array}{l}\text { Flood death judgement of } \\
\text { people needing to be } \\
\text { rescued after earthquake }\end{array}$ & $\begin{array}{l}\text { Evacuation rate was assumed to be 0\%, and critical water level band (Fig. 5) } \\
\text { was assumed to be from the ground floor level upward. }\end{array}$ \\
\hline $\begin{array}{l}\text { Flood death judgement of } \\
\text { people staying in partially } \\
\text { destroyed house }\end{array}$ & $\begin{array}{l}\text { It was assumed that evacuation to the higher floor was impossible regardless of } \\
\text { the age, and safe water level band, near-critical water level band, and critical } \\
\text { water level band were assumed from the ground floor level upward in order. }\end{array}$ \\
\hline $\begin{array}{l}\text { Evacuation possibility } \\
\text { before flood }\end{array}$ & $\begin{array}{l}\text { Evacuation rate of evacuees who had evacuated to an evacuation center due to } \\
\text { the earthquake was assumed to be } 100 \% \text {, that of people staying home } 40 \%, \text { and } \\
\text { that of people in power outage } 0 \% \text { when the flood was imminent. }\end{array}$ \\
\hline
\end{tabular}

"Number of deaths" = "Mortality according to the maximum inundation depth and house damage condition (totally/partially destroyed or not)" $\times$ "Number of people staying home (not including the evacuees and the deceased) by house damage condition"

\subsection{Result of flood simulation}

Some of the results of the flood simulation are shown in Fig. 6. The influence of the levee subsidence caused by the earthquake is clearly presented by comparing the cases of the $\mathrm{F}_{\mathrm{b}}$ flood without an earthquake and that just after the L2 earthquake, when the subsidence of the levee was estimated to be maximum. The average inundation depth just after the L2 earthquake was about $30 \%$ larger than that without an earthquake; similarly, the inundation area was about $50 \%$ larger. The difference in the inundation depth and area by the scale of the earthquake was not noticeable, because the difference in the amount of subsidence among the earthquakes was small.

\subsection{Flood damage estimation and analysis}

The number of people at home in the area (who were not in the evacuation center), the emergency levee reconstruction rate, and the number of deaths by the $\mathrm{F}_{\mathrm{b}}$ flood in accordance with the number of days from the earthquake to the flood are shown in Fig. 7. The number of deaths by the flood became much larger than that by the flood without the earthquake. The number of deaths caused by the $F_{b}$ flood without the earthquake was 460 , and that by the $F_{c}$ flood was 0 .

A big difference is seen in the number of deaths caused by the $F_{b}$ flood just after the L2 earthquake and just after the L1' earthquake; namely, the number of deaths just after the L2 earthquake was about $40 \%$ larger than that just after the L1' earthquake, even though no noticeable difference is seen in the inundation depth and area between them, as mentioned in Section 6.1. The reason for the difference was inferred to be the difference in the number of the houses damaged by the earthquake (namely, the number of houses totally or partially destroyed by the L2 earthquake was about 2 times larger than that by the L1' earthquake, as shown in Table 3). The number of houses damaged by the earthquake had a major impact on the number of deaths by the flood, because the number increased with the increasing flood mortality of the people in the house waiting for rescue after the earthquake, and with the difficulty of evacuating to a higher floor of the house.

Especially, in the case of the $F_{b}$ flood just after the earthquake, the number of deaths became larger than that by the earthquake without the flood, as shown in Table 3. On the other hand, the number of deaths greatly decreased in accordance with the progress of the emergency levee reconstruction. However, the number of deaths by the $\mathrm{F}_{\mathrm{b}}$ and $\mathrm{F}_{\mathrm{c}}$ floods at the time of $50 \%$ completion of the emergency levee reconstruction were larger than those at the time of $20 \%$ completion. The reason was the number of people at home at the time of the $50 \%$ completion was larger than that of the $20 \%$ completion, because of the increased number of people going back home due to the progress of water supply recovery in the area. 


\section{ESTIMATION AND ANALYSIS OF EFFECT OF DAMAGE REDUCTION MEASURES AGAINST MULTIPLE DISASTERS}

We assumed four cases of measures, and estimated each effect against the multiple disasters as follows:

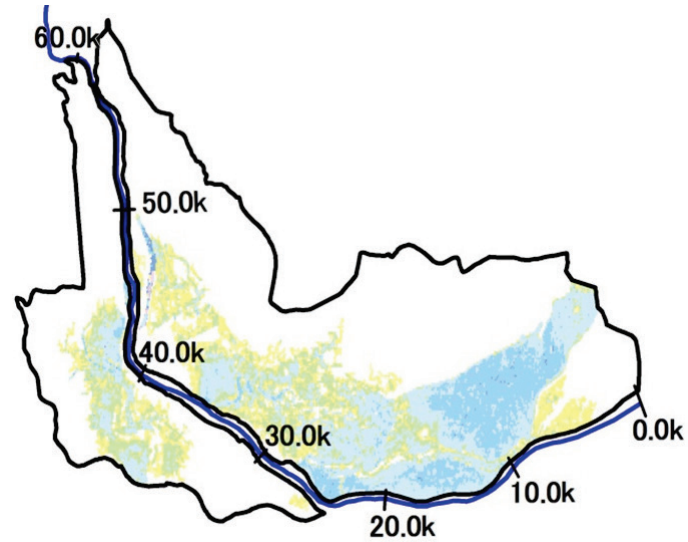

(a) $F_{b}$ Flood without earthquake

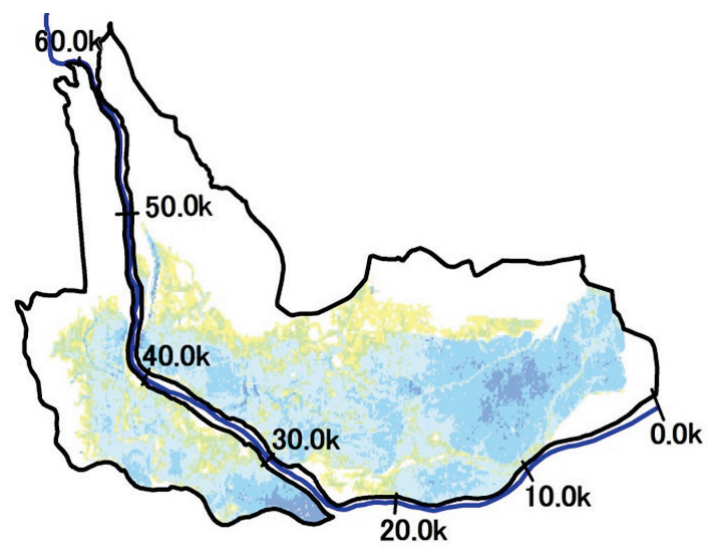

(b) $\mathrm{F}_{\mathrm{b}}$ Flood just after L2 earthquake

Fig. 6 Examples of flood simulation

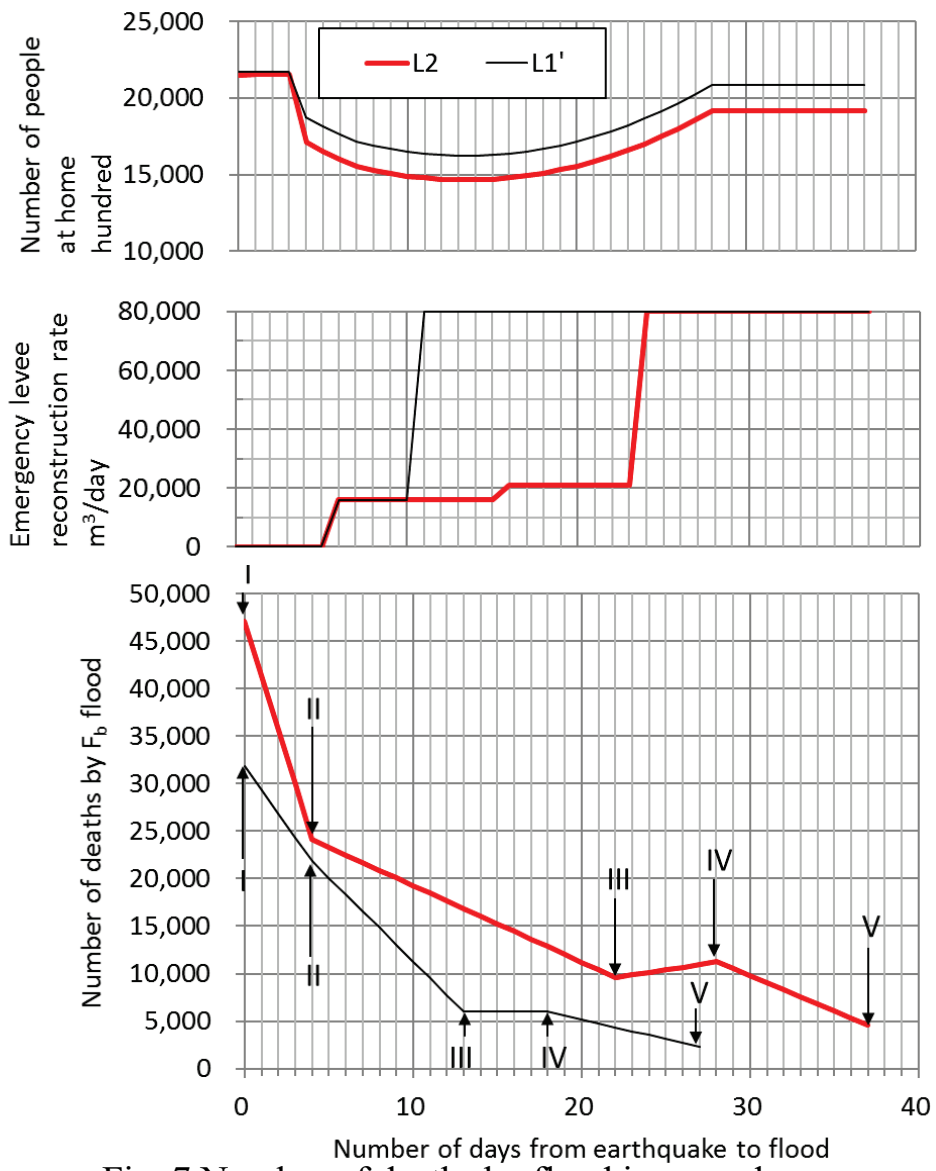

Fig. 7 Number of deaths by flood in accordance with number of days from earthquake

- Measure case 1: Stockpiling the machines, equipment, and materials required for $100 \%$ completion of the emergency levee reconstruction within two weeks after the earthquake.

- Measure case 2: Stockpiling the machines, equipment, and materials required for $50 \%$ completion of the emergency levee reconstruction within two weeks.

- Measure case 3: Strengthening the levee structure to be capable of withstanding earthquakes at the same cost (for 50 years) as the measure case 2 .

- Measure case 4: Strengthening the levee structure as in the measure case 3, and adding to it, stockpiling the machines, equipment, and materials with the same cost of "difference in cost between measure case 1 and measure case 3 for 50 years", i.e., the total cost (sum of the levee structure strengthening and stockpiling) is almost the same as measure case 1.

For comparing and analyzing the results, a graph of the number of days from the earthquake to the flood (horizontal axis) versus the estimated flood damage (vertical axis) was drawn for each case. "Relative risk" was defined as the area between the horizontal axis and the curve (polygonal line) on the graph from the earthquake to the completion day of emergency levee reconstruction, as follows:

$$
\text { "Relative risk" }=\int \mathrm{R}(\mathrm{t}) \mathrm{dt}
$$


where $t$ is the number of days between the earthquake and the flood, $R(t)$ is "flood damage" as a function of the "number of days between the earthquake and the flood". The interval of the integration is from $t=0$ to $t=t_{e}$, where $t_{e}$ is the number of days from the earthquake to the completion of the emergency levee reconstruction.

By using the relative risk, the "damage reduction ratio" was estimated and analyzed as follows:

"Damage reduction ratio" = ("Relative risk without the measure" - "Relative risk with the measure")/"Relative risk without the measure"

\subsection{Influences of earthquake on flood damage}

It is assumed that the damage on the river infrastructure and buildings, roads, etc. in the floodplain had an impact on the flood damage by mainly three influences, as follows:

(1) Flood damage worsening by the increase of the inundation area and depth due to subsidence of the levee.

(2) Human damage worsening during the flood because evacuation to the second floor or higher of a destroyed house became difficult and/or access to flood alerts became difficult due to power outage.

(3) Apparent decrease of the direct economic damage by the flood because of the decrease of the value of the assets in the floodplain due to the earthquake damage.

The results of the estimation of the number of deaths by the $\mathrm{F}_{\mathrm{b}}$ and $\mathrm{F}_{\mathrm{c}}$ floods after the L2 and L1' earthquakes are shown in Fig. 8, and that of direct economic damage by the $\mathrm{F}_{\mathrm{b}}$ flood in Fig. 9. The number of deaths by the flood increased as the scale of the earthquake became larger. This is probably because the influences of (1) and (2) above were larger. On the other hand, the direct economic damage by the flood just after the earthquake decreased as the scale of the earthquake became larger, as shown in Fig. 9. This is probably because the influence of (3) above became larger. It is supposed that a multi-axis evaluation (i.e., multi-index of damage evaluation) is also important in the study of damage reduction measures against multiple disasters; at a minimum, the direct economic damage and the number of deaths should be included in the target indexes.

\subsection{Difference in characteristics of effect between stockpiling and structural strengthening}

The effect of damage reduction by the structural strengthening measure (measure case 3) was, of course, clearly presented by the large difference in flood damage from the time just after the earthquake compared to that by the stockpiling measure (measure case 2), as shown in Fig. 8. For example, the damage reduction ratio in the number of deaths by the $\mathrm{F}_{\mathrm{b}}$ flood after the L2 earthquake was $46 \%$ for measure case 2 , but $72 \%$ for measure case 3 ; that is, measure case 3 was more than $20 \%$ larger. It is supposed that confirming the larger effect in damage reduction against the multiple disasters by the structural strengthening measure over that by the stockpiling measure is important when discussing the priorities of alternative measures for disaster damage reduction in an area.

\subsection{Influences of flood scale on estimating damage reduction effects of measures}

The apparent effect of damage reduction of each measure was different according to the scale of the flood. For example, the apparent effects of damage reduction by measure cases 3 and 4 in the number of deaths by the $F_{b}$ flood was larger than that by the $F_{c}$ flood in general, as shown in Fig. 8. According to the damage reduction ratio, for example, in the number of deaths was $72 \%$ for measure case 3 with the $\mathrm{F}_{\mathrm{b}}$ flood after the L1' earthquake, but only $60 \%$ (over $10 \%$ less) with the $\mathrm{F}_{\mathrm{c}}$ flood. It is supposed that the estimation of the damage reduction effects for multiple scales of floods is necessary in some cases to compare the effects of alternative damage reduction measures against multiple disasters. 


\subsection{Influences of earthquake scale on estimating damage reduction effects of measures}

The apparent effect of damage reduction of each measure was different according to the scale of the earthquake. For example, the damage reduction ratio in the number of deaths by the $\mathrm{F}_{\mathrm{b}}$ flood and measure case 2 was $46 \%$ for the L2 earthquake, but only $21 \%$ for the L1', as shown in Fig. 8. It is
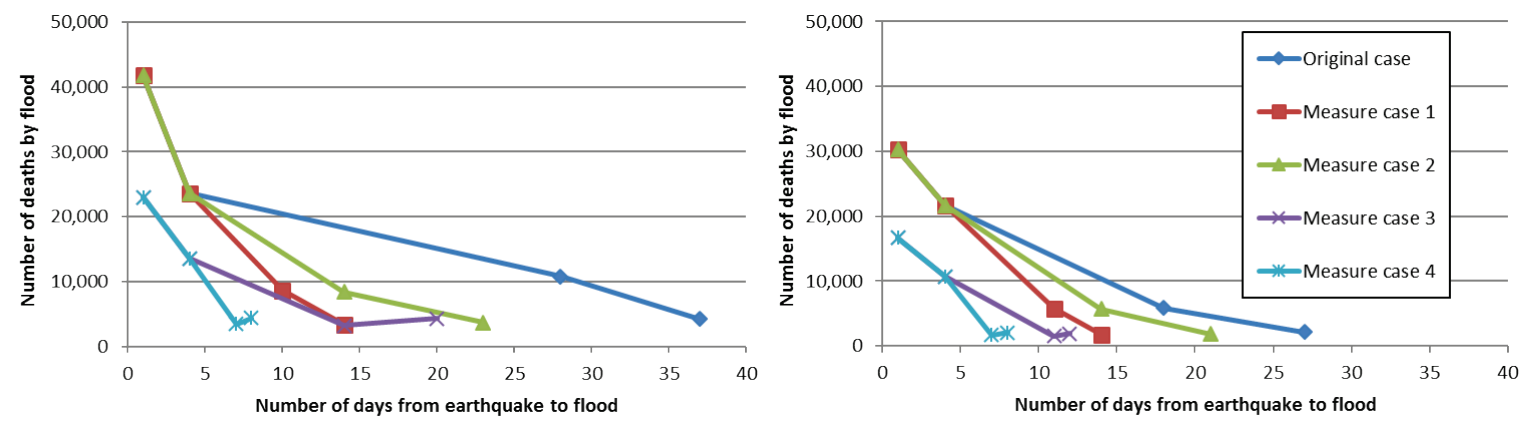

$\left(\mathrm{F}_{\mathrm{b}}\right.$ flood $)$
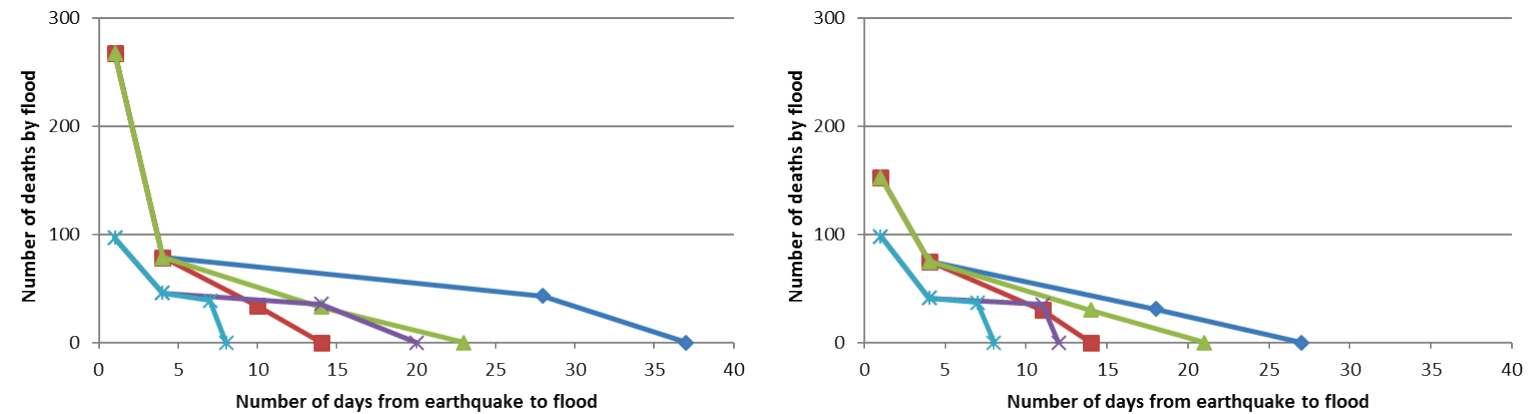

$\left(\mathrm{F}_{\mathrm{c}}\right.$ flood $)$

Fig. 8 Effect in number of deaths of each measure

(Left: L2 earthquake, Right: L1' earthquake)
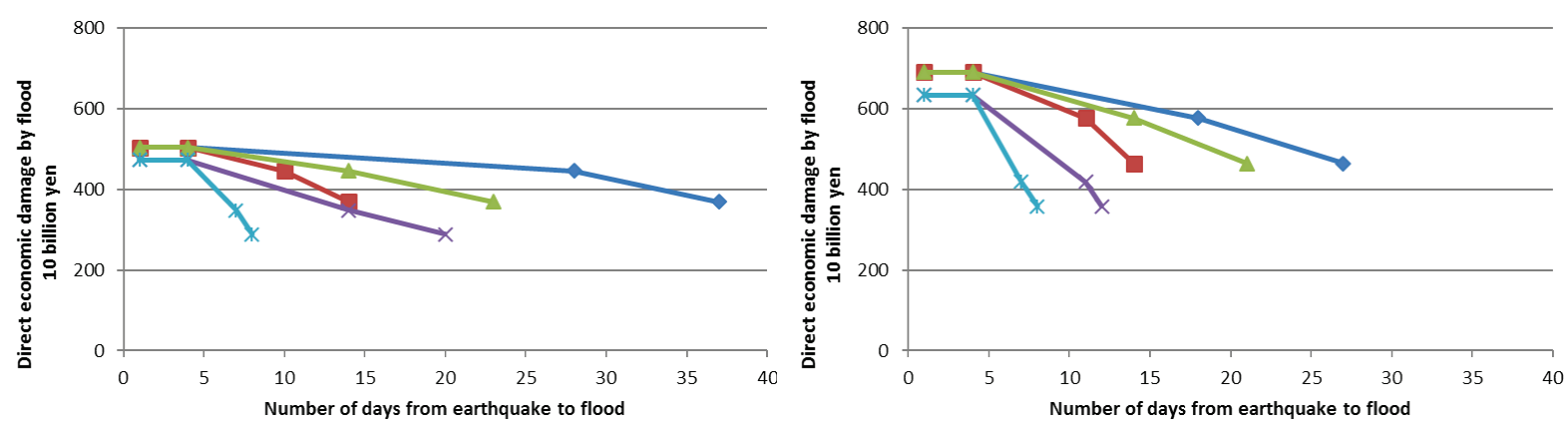

$\left(\mathrm{F}_{\mathrm{b}}\right.$ flood $)$

Fig. 9 Effect in direct economic damage of each measure

(Left: L2 earthquake, Right: L1' earthquake)

supposed that house damage, which increased the mortality by the flood, was less in the L1' earthquake than that in L2 (Table 3), and the apparent effect of damage reduction through the earlier progress of reconstruction of the measure seemed to be smaller for L1'. It is supposed that estimation of the damage reduction effects for multiple scales of earthquakes is necessary in some cases in order to compare the effects of alternative damage reduction measures against multiple disasters. 


\section{CONCLUSIONS}

The authors applied the analysis method suggested by Matsuura et al. ${ }^{5)}$ to a river for a total of 120 cases of estimation with three scales of earthquakes, two scales of floods, four intervals between the earthquake and the flood, and five cases of measures (including the original case without measures), and analyzed the damage reduction effect of each measure. The following results were found.

(1) It was illustrated that the flood damage in the number of deaths and the direct economic damage changed according to the scales of the earthquake and the flood. The number of deaths by the flood increased as the scale of the earthquake became larger, but the direct economic damage by the flood apparently decreased in some cases with the larger earthquake. It was supposed that considering multiple damage indexes is important when discussing the measures against the multiple disasters.

(2) It was illustrated that the damage reduction effect of the measure of strengthening a levee structure against an earthquake was different from the measure of stockpiling equipment, machines, and materials for earlier progress of the emergency levee reconstruction. The effect of the structural measure was especially large just after the earthquake, and it was larger than that by the stockpiling measure up to completion of the emergency levee reconstruction. It was supposed that the structural measure's priority should be raised higher, especially where quick emergency levee reconstruction seems difficult in an area.

(3) It was illustrated that the damage reduction effect of each measure was different according to the scales of the earthquake and the flood. It was supposed that multiple scales of earthquakes and floods should be considered when estimating and discussing measures against the disaster rather than considering only one specific scale each of the earthquake and flood.

From the abovementioned three results, the authors think that the method used in this study for estimating, analyzing, and illustrating the potential disaster damage by systematically setting the scale of the earthquake and the flood, along with the interval between the earthquake and the flood, is effective for analyzing and discussing the measures against the disasters.

It is planned to study disaster risk reduction measures against multiple disasters in a river basin by integrating a wide range of measures, such as river improvement and strengthening the levee structure, evacuation roads, and houses against earthquakes in the floodplain.

\section{ACKNOWLEDGMENT}

The authors appreciate Sendai General Construction Association, Miyagi Demolition Work Business Cooperative, and River Planning Division of Tohoku Regional Development Bureau, River Construction Division and Shinano-gawa River Office of Hokuriku Regional Development Bureau, MLIT, for providing the materials on the emergency response works after the Great East Japan Earthquake in 2011, Niigata-ken Chuetsu Earthquake in 2004, and Niigata-ken Chuetsu-oki Earthquake in 2007 referenced in this study.

\section{REFERENCES}

1) Rivers Tsunami Measures Study Group: Urgent Proposal to Tsunami Run-up to Rivers, MLIT, 2011 (in Japanese).

2) Hattori A., Itagaki O., Tsuchiya S., Kato T., and Fujita K.: Macro-Evaluation of Climate Change Impact on Flood Control Measures in Japan, Advances in River Engineering, Vol.18, Japan Society of Civil Engineers, 2012, pp.481-486 (in Japanese).

3) Central Disaster Prevention Council: 1948 Fukui Earthquake, $4^{\text {th }}$ Report of Expert Committee for Inheritance of Disaster Lessons, Cabinet Office, 2011 (in Japanese).

4) Kawata Y.: New Threats of Natural Disaster and Disaster Response Challenges, Disaster Reduction Management, Vol.3, 2008, pp.14-20 (in Japanese). 
5) Matsuura T., Itagaki O., and Hattori A.: Case Study on Potential Damage and the Damage Characteristics by the Multiple Disaster of Earthquakes and Floods, Advances in River Engineering, Vol.20, Japan Society of Civil Engineers, 2014, pp.385-390 (in Japanese).

6) Central Disaster Prevention Council: Measures against massive Nankai Trough earthquake (Final Report) - Seismic Image of massive Nankai Trough earthquake -, Cabinet Office, 2013 (in Japanese).

7) Central Disaster Prevention Council: Damage Estimation on To-Nankai and Nankai Earthquake, $14^{\text {th }}$ article of Expert Committee on To-Nankai and Nankai Earthquake, 2003 (in Japanese).

8) Fire and Disaster Management Agency: Great East Japan Earthquake Record Collection, 2013 (in Japanese).

9) Central Disaster Prevention Council: Overview of Damage Estimation Items and Technique on massive Nankai Trough earthquake, Cabinet Office, 2013 (in Japanese).

10) Shoji G., Takahashi D., Tsukiji T., Naba S.: Damage Assessment on Electric Power Failures during the 2011 off the Pacific Coast of Tohoku Earthquake, Journal of JSCE, A1, Vol.68, No.4, 2012, pp.I_1210-I_1223 (in Japanese).

11) Shoji G., Toyota A.: Function of Emergency Road Networks during the Post-Earthquake Process of Lifeline Systems Restoration, Journal of Disaster Research, Vol.7, No.2, 2012, pp.173-183.

12) Chubu Region Highway Council: 2012 Teeth Comb Strategy in Chubu Region, 2013 (in Japanese).

13) Shoji G. and Nakamura T.: Development of Damage Functions on Road Infrastructures Subjected to Extreme Ground Excitations by Analyzing Damage in the 2011 Off the Pacific Coast of Tohoku Earthquake, Journal of Disaster Research, Vol.9, No.2, 2014, pp.121-127.

14) Kinki Regional Development Bureau: Learning from Experiences in the Great Hanshin-Awaji Earthquake, MLIT, 2002 (in Japanese).

15) Kawakami E.: Relation among JMA Seismic Intensity, Damage Ratio and Water Outage Ratio, Proceedings of the 53 ${ }^{\text {rd }}$ Annual Conference of JSCE, 1998, pp.646-647 (in Japanese).

16) Nagoya City Water Works and Sewerage Bureau: Business Continuity Plan against Earthquake, 2012 (in Japanese)

17) Nagata S., Kageyama K., Yamamoto K.: An Emergency Restoration Model for Water Supply Network Damage due to Earthquakes, Journal of Disaster Research, Vol.3, No.6, 2008, pp.390-399.

18) Tokyo Metropolitan Government's Disaster Prevention Council: Damage Estimation Report on Tokyo Inland Earthquake, 2012, pp.3-67, 3-70 (in Japanese).

19) River Improvement and Management Division: Seismic Inspection Manual for River Levee against Level 2 Ground Motion, Water and Disaster Management Bureau, MLIT, 2012, pp.17 (in Japanese).

20) River Improvement and Management Division: Seismic Performance Verification Guidelines with Explanation for River Structures, Water and Disaster Management Bureau, MLIT, 2012 (in Japanese).

21) Gifu Prefecture Government: Gifu Prefecture Tokai Earthquake Damage Response Scenario Study Report, 2004 (in Japanese).

22) Water and Disaster Management Bureau: Flood Control Economic Survey Manual (draft), MLIT, 2005 (in Japanese).

23) Water and Disaster Management Bureau: Flood Damage Indicators Analysis Guide (2013 Trial Version), MLIT, 2013, pp.23-25 (in Japanese). 